\title{
¿"We Would Ride Safely in the Harbor of the Future": Historical Parallels between the Existential Threats of Yellow Fever and Sea Level Rise in New Orleans and Norfolk
}

\author{
MORRIS W. FOSTER AND EMILY E. STEINHILBER \\ Institute for Coastal Adaptation and Resilience, Old Dominion University, Norfolk, Virginia
}

(Manuscript received 16 October 2018, in final form 7 June 2019)

\begin{abstract}
The nineteenth-century experiences of yellow fever epidemics in New Orleans and Norfolk present historical parallels for how those cities, and others, are experiencing existential threats from climate change and sea level rise in the twenty-first century. In particular, the nineteenth-century "sanitary reform" movement can be interpreted as a model for challenges facing twenty-first-century "climate resilience" initiatives, including denialism and political obfuscation of scientific debates as well as tensions between short-term profit and the cost of long-term infrastructure investments and between individualism and communitarianism. The history of sanitary reform suggests that, at least in the United States, climate resilience initiatives will advance largely on a regional basis through extended local debates around these and other challenges until resilient infrastructure and practices are taken for granted, much as sanitary waterworks and sewers are today.
\end{abstract}

\section{A tale of two cities}

New Orleans, Louisiana, and Norfolk, Virginia, both low-lying port cities with centuries-long histories, often are cited among U.S. cities that are most vulnerable to sea level rise (Hallegatte et al. 2013). Both cities frequently are called out in studies that predict which urban places may be abandoned to inundation by the end of the twenty-first century (Strauss et al. 2015). This is not the first time, though, that the two cities have been equated as facing a common existential threat.

During the nineteenth century, New Orleans and Norfolk were among coastal cities that experienced repeated outbreaks of yellow fever, resulting in large losses of life. New Orleans had 36 significant outbreaks that century while Norfolk had 8 (Patterson 1992). The greatest losses in New Orleans occurred in 1853 (more than 9000 dead) and in Norfolk in 1855 (more than 3000 dead), roughly $10 \%$ of the total population in each, the chronological proximity of which became the basis for contemporaneous comparisons of the two cities (Dowler 1859).

Like climate change in the present century, repetitive nineteenth-century epidemics of yellow fever (as well as

๑ Denotes content that is immediately available upon publication as open access.

Corresponding author: Morris W. Foster, mfoster@odu.edu cholera, smallpox, and typhus) were perceived globally as a long-term challenge to human civilization (Barton 1857). Efforts to eliminate such epidemics spanned decades, lasted well into the twentieth century, and continue to be waged in less developed parts of the world. The primary nineteenth-century response to those epidemics, "sanitary reform," can be viewed as a historical model for "resilience" responses to climate change in the twenty-first century. Sanitary reform resulted in the clean water and sanitation infrastructure that we take for granted today. While water and sanitation were of concern prior to the nineteenth century, the significant increase in urban population densities in that century greatly exacerbated diseases, resulting in hundreds of thousands of deaths, to which unsanitary conditions contributed by heightening contagious communicability and disease vectors such as mosquitoes and lice.

Most historical accounts of sanitary reform treat it as an inevitable progressive outcome, with little discussion of its ups and downs (Leavitt 1980). At the time, however, the movement was a struggle that lasted more than 80 years due to unsettled science (both within and outside the movement), competing philosophies of individual rights and communal responsibilities, and tensions between short-term private sector profits and long-term public sector expenditures on sanitary infrastructure (Allen 2002). 


\section{a. Scientific contestation}

Sanitary reform began in the United Kingdom, promoting a "miasmic" theory of disease that blamed gases emanating from rotting organic matter as the causes. Miasmic explanations spread to the United States and became the initial basis for a social movement there as well. Interestingly, scientific disagreements within the movement between miasmic theorists and proponents of the emerging germ theory of disease were quite bitter (Richmond 1954). Those scientific disagreements were used by opponents of investments in public sanitary infrastructure to cast doubt on the need for reform. For example, disagreements within the New Orleans medical community as to the scientific causes of the yellow fever epidemic of 1853 were used to justify sanitary inaction, as noted in the New Orleans Bee in 1855 (Postell 1942):

After all our knowledge respecting yellow fever, its causes and the means of preventing its appearance is equally empirical and unsatisfactory. What can we really know of the occult agencies which generate the disease, when we see some scientific men proclaiming it indigenous, while others affirm that it is imported; one stoutly maintaining that filth engenders it, while another strenuously argues the reverse; Medicus No. 1 confidently asserting that quarantine is our only salvation, Medicus No. 2 ridiculing with inextinguishable laughter the idea that the disease is of foreign origin. The upshot of these diametrically opposite conclusions is that we are wholly ignorant of the causes of yellow fever.

Although miasmic theory and germ theory offered conflicting explanations of the lived experience of yellow fever in New Orleans, Norfolk, and elsewhere, most of the sanitary recommendations made by proponents of each-including centralized water, sewerage, and drainage systems - were the same. Yet, even as late as the early twentieth century, some physicians in New Orleans continued to cast doubt on the health benefits of a public sewerage system (Behrman 1914):

In New Orleans the opinion was prevalent that the construction and operation of sewers would be a nuisance and a menace to health, and this opinion was in a measure held be some physicians, who withheld their approval for several years as to the advisability of using sewers, fearing obnoxious exhillations and the communication of contagious diseases.

As is the case today with climate change, the existence of public disagreement about the causes of yellow fever was equated with uncertainty about how to mitigate its consequences. Denialism also was practiced in the midst of observable outbreaks. At the height of the worst yellow fever epidemics, fearful of a loss of business, newspapers in both New Orleans (in 1853) and Norfolk (in 1855) minimized reports of illness and mortality while asserting the "salubrious" nature of their respective climates (Bryant 1856; Carrigan 1959; McKiven 2007). With similar fears of business loss echoing, but an acknowledgment of the scientific concensus that seas are rising, both Norfolk and New Orleans are taking a different approach this time. Both are actively positioning themselves as global centers of innovation for climate resilience (Filer et al. 2017; Plyer et al. 2017).

While the twenty-first-century science of climate change is more settled than was the nineteenth-century science of infectious disease, resistance to both climate resilience and sanitary reform takes advantage of the evolving nature of scientific explanation of observed phenomena, which necessarily works through a process of critically questioning and revising explanatory theories, to inflate doubt as a rationale for maintaining the status quo.

\section{b. Financial barriers}

The cost of sanitary infrastructure-clean waterworks, sewers, waste treatment facilities, and regular street cleaning-also was used as an argument against reform, most often through the comparison of short-term costs to business as usual against long-term collective benefits (Goldfield 1976). For example, in the immediate aftermath of the 1855 yellow fever epidemic, Norfolk was granted approval by the Virginia General Assembly to issue bonds for waterworks. However, resistance to paying the property millage on the bonds as well as national economic downturns delayed the realization of those waterworks until 1873 (Burton 1877). During the intervening years, citizens in favor of sanitary reform organized parades, fireworks, and other public events to counter resistance to the costs of public sanitation on the part of segments of the business community. As the Norfolk Post editorialized on 28 August 1865:

They have been talking about supplying their city with water for the past century, and are farther now from the adoption of any feasible plan than when the question was first raised. They are fully impressed with the urgent necessity of having a constant and abundant supply of good and wholesome water, but are appalled at the immensity of the undertaking, at the exertion, labor and money it will require; and so they postpone action in the matter year after year, relying upon their stagnant cisterns, filled with dead vermin and the filth of the gutters ... It is a grievous $\sin -\mathrm{a}$ burden we can no longer afford to bear, and, with many other dead weights, we must cast it into the sea of the past, if we would ride safely in the harbor of the future.

Similar resistance to accepting short-term costs to mitigate a long-term existential threat is echoed today in 
political debates about mitigating and adapting to climate change through reducing carbon emissions and constructing public works, respectively. In 2016, for example, the Virginia General Assembly established the Virginia Shoreline Resiliency Fund; however, this revolving loan fund has remained unfunded though the issue is raised by citizens and members of the legislature each year. Meanwhile municipalities such as Norfolk estimate their infrastructure adaptation costs to be in the billions with long-term benefits far exceeding the projected costs (U.S. Army Corps of Engineers 2018).

Because the threats addressed are population level, sanitary reform and climate resilience both necessarily are premised on large-scale changes in human behavior and major public infrastructure investments. As in the case of nineteenth-century resistance to sanitary reform (Ogle 1999), economic resistance to climate resilience is based in part on a rhetoric of individualism that prioritizes short-term economic gains versus state-imposed mandates that prioritize the long-term communal good. Conflict between individualism and collectivism has been identified as a central dynamic in environmental decision-making generally (McCarty and Shrum 2001; Morren and Grinstein 2016).

\section{c. Top down, bottom up}

"Sanitary reform" and "climate resilience" are, at once, scientifically based transnational movements in response, respectively, to global epidemics and climate change that know no political boundaries as well as politically bounded local efforts to adapt to the groundlevel consequences of those phenomena. Although the larger scientific and policy issues were debated on national and international stages, much of the work of sanitary reform was done locally. In the course of that nineteenth-century process, both New Orleans and Norfolk necessarily developed more centralized municipal polities with more robust revenue sources. It is likely that climate resilience will play out in a similar manner (Foster et al. 2018), with attention already being given to the role that urban entities will play in "climate change governance" (Bulkeley 2010).

New Orleans and Norfolk are examples of how resilience may become more a part of local public consciousness in the future. Citizens of the two cities already encounter the consequences of climate change on a regular basis. As a result of that shared lived experience, public discourses in the two cities offer examples of how citizens and their local representatives more directly grapple with the trade-off of short-term costs and individualism with long-term benefits and communal interests.

In New Orleans, a study of representative stakeholders showed a consistent internalization of communal values-"protecting and promoting healthy ecosystems and biodiversity" and "preserving New Orleans' unique culture, traditions, and historically significant neighborhoods"-alongside more individually oriented economic values with respect to climate risk management (Bessemer et al. 2017). In Hampton Roads (the larger region composed of 17 localities of which Norfolk is one), a variety of venues and sponsoring groups have hosted what amounts to an ongoing discussion about how to collaborate as a single regional community on adaptations to sea level rise, across political boundaries that traditionally have been resistant to working together (Considine and Steinhilber 2018). Moreover, surveys of residents in Hampton Roads show a growing belief that flooding in the region has increased over recent decades (Gainey and Vandecar-Burdin 2018).

Based on the history of sanitary reform, working out barriers to communal interests and collaborations within and between specific local contexts could be the critical step in realizing national and international goals for climate resilience.

\section{d. Lessons of sanitary reform}

The trajectory of sanitary reform in New Orleans and Norfolk may hold lessons for climate resilience. As Melosi (2008) notes, the accomplishment of public sanitation in the nineteenth and early twentieth centuries depended on local combinations of a variety of factors: emerging awareness due to scientific and educational efforts, emerging technologies for water and sewer systems (including pumps and filtration), emerging means for public financing (including municipal bonds and taxes), ongoing political dynamics that used sanitary reform proposals as points of partisan contention, and the perception that a "modern" sanitary city would be more attractive to business.

In both New Orleans and Norfolk, the progress of sanitary reform played out through the lenses of local political rivalries and the gradual emergence of centralized municipal services and tax bases to fund those, but it also continued to have local political and economic consequences long after sanitary infrastructure was implemented.

Prior to 1908 , New Orleans relied primarily on a privatized water system that delivered largely nonpotable water to limited sections of the city, while a municipal sewerage system was not constructed until 1903 (Behrman 1914). The performance of the private water system, along with other aspects of city sanitation, was a key political issue for over three decades as "reform" and "machine" political factions took turns running the city (Kolb 2000). Ultimately, public water and sewerage systems using stateof-the-art technologies won out after continued outbreaks 
of yellow fever and waterborne diseases, but then were constructed preferentially in segregated neighborhoods, thereby increasing racial health disparities (Troesken 2001).

In Norfolk, financing and public acceptance were continuing issues for first establishing and then expanding and upgrading a public water system as well as the construction of a sewerage infrastructure. Even after those systems were put in place in the 1880s, many households initially were reluctant to hook up to them (Waring 1891). In the 1930s, as the practice of pumping sewage into the Chesapeake Bay poisoned oyster beds and contributed to water quality deterioration, the idea of using public funds to construct the first Norfolk sewage treatment plant became a contentious political issue between long-established political factions in the context of local implementation of federal New Deal programs (Lillis 2015).

\section{e. Finding a safe harbor}

Similar combinations of awareness, technology, financing methods, political dynamics, and municipal modernity or progressiveness are evident in current public discourse about resilience to climate change. As in the case of sanitary reform, awareness is the first hurdle to overcome, but developing effective technologies and practices along with viable public and private financing methods and then navigating political dynamics that use the existential threat of climate change to fuel partisanship can be even more challenging.

In reviewing the experiences of New Orleans and Norfolk with respect to sanitary reform, the availability of innovative financing models for water, sewerage, and drainage infrastructure was a recurring challenge that often took years to resolve. Arguably, work done now in devising innovative ways to finance local resilience infrastructure projects as well as support "low carbon" changes in behavior could speed implementation once the thresholds of public awareness and political contestation are overcome. Being able to present those financial approaches as reducing economic risks and losses, and even as producing positive returns on investments, could help turn public and political sentiment in favor of resilient choices. Investments in resilience also can be presented as a way to attract visitors and business to a locality, just as investments in public sanitation ultimately were portrayed.

In addition to being associated with changes in municipal financial instruments, the implementation of sanitary reform also was associated with changes in municipal polities, as both New Orleans and Norfolk developed more centralized governments to fund, build, and operate sanitary infrastructure. Changes in behavior and infrastructure will require greater coordination across municipal, county, and other local political subdivisions. Both Louisiana and Virginia have been challenged by limited legal paths to enable such crossjurisdictional collaboration in response to the effects of climate change (Lewis and Ernstson 2019; Considine and Steinhilber 2018). Legislating those paths prospectively could accelerate the implementation of multilocality regional adaptation and mitigation strategies.

Once climate resilience is implemented on a large scale, however, it may be seen retrospectively as having been as inevitable a product of "human progress" as public sanitation now is perceived. The institutionalization of extensive adaptations (such as sanitary reform and climate resilience) in the fabric of everyday life necessarily requires a cultural or value change to facilitate their acceptance, thus casting each retrospectively as inevitable and unquestionable (Tarr et al. 1984). While evidence suggests that cultural turn now is well advanced in New Orleans and Norfolk, an additional historical lesson of sanitary reform is that such local shifts precede, by some years, the formation of a national consensus.

Acknowledgments. This work was supported by funding from the Commonwealth Center for Recurrent Flooding Resiliency.

\section{REFERENCES}

Allen, M., 2002: From cesspool to sewer: Sanitary reform and the rhetoric of resistance, 1848-1880. Victorian Lit. Cult., 30, $383-$ 402, https://doi.org/10.1017/S1060150302302018h.

Barton, E. H., 1857: The Cause and Prevention of Yellow Fever at New Orleans and Other Cities in America. H. Baillière, 380 pp.

Behrman, M., 1914: New Orleans: A History of the Three Great Public Utilities: Sewerage, Water, and Drainage and their Influence upon the Health and Progress of a Big City. Brandao Print, 16 pp.

Bessemer, D. L., L. A. Mayer, B. Cwik, M. Vezér, K. Keller, R. J. Lempert, N. Tuana, 2017: Building a values-informed mental model for New Orleans climate risk management. Risk Anal., 37, 1993-2004, https://doi.org/10.1111/risa.12743.

Bryant, J. D., 1856: The Epidemic of Yellow Fever in Norfolk and Portsmouth, Virginia, During the Summer and Fall of 1855. T.K. and P.G. Collins, 39 pp.

Bulkeley, H., 2010: Cites and the governing of climate change. Annu. Rev. Environ. Resour., 35, 229-253, https://doi.org/ 10.1146/annurev-environ-072809-101747.

Burton, H. W., 1877: The History of Norfolk, Virginia. A Review of Important Events and Incidents which Occurred from 17361877; Also a Record of Personal Reminiscences and Political, Commercial, and Curious Facts. Norfolk Virginian, 264 pp.

Carrigan, J. A., 1959: Yellow fever in New Orleans, 1853: Abstractions and realities. J. South. Hist., 25, 339-355, https:// doi.org/10.2307/2954767.

Considine, C., and E. Steinhilber, 2018: Collaborative strategies for sea level rise adaptation in Hampton Roads, Virginia. J. Green Build., 13, 193-214, https://doi.org/10.3992/1943-4618.13.3.193.

Dowler, M. M., 1859: Observations and reflections on yellow fever. New Orleans Med. Surg. J., 16, 305-324. 
Filer, L., R. Clower, M. White, S. Shanhjoltz, R. Dale, and J. McClure, 2017: Go Virginia region 5 growth and diversification plan: Moving Hampton Roads forward. Go Virginia, 93 pp., https://www.dhcd.virginia.gov/sites/default/files/Docx/ gova/region-five/region-5-growth-diversification-plan.pdf.

Foster, M., J. O'Donnell, M. Luckenbach, E. Andrews, E. Steinhilber, J. Wells, and M. Davis, 2018: Institutionalizing resilience in US universities: Prospects, opportunities, and models. Mar. Technol. Soc. J., 52, 106-110, https://doi.org/ 10.4031/MTSJ.52.2.10.

Gainey, R., and T. Vandecar-Burdin, 2018: Life in Hampton Roads report: The ninth annual life in Hampton Roads survey. Old Dominion University, 67 pp., https://www.odu.edu/content/ dam/odu/col-dept/ssrc/docs/lihr-report-2018-final.pdf.

Goldfield, D. R., 1976: The business of health planning: Disease prevention in the old south. J. South. Hist., 42, 557-570, https:// doi.org/10.2307/2208006.

Hallegatte, S., C. Green, R. J. Nicholls, and J. Corfee-Morlot, 2013: Future flood losses in major coastal cities. Nat. Climate Change, 3, 802-806, https://doi.org/10.1038/nclimate1979.

Kolb, C., 2000: Trickle by trickle: Municipalization of the New Orleans water system in the nineteenth and early twentieth centuries. University of New Orleans College of Urban and Public Affairs Working Papers, 23 pp., https://scholarworks.uno.edu/cupa_wp/11.

Leavitt, J. W., 1980: The wasteland: Garbage and sanitary reform in the nineteenth century American city. J. Hist. Med. Allied Sci., 35, 431-452, https://doi.org/10.1093/jhmas/XXXV.4.431.

Lewis, J. A., and H. Ernstson, 2019: Contesting the coast: Ecosystems as infrastructure in the Mississippi River delta. Prog. Plann., 129, 1-30, https://doi.org/10.1016/j.progress.2017.10.003.

Lillis, T., 2015: Ensuring future generations inherit clean waterways: HRSD's first 75 years. Hampton Roads Sanitary District, 17 pp., https://www.hrsd.com/sites/default/files/assets/Documents/ pdfs/HRSDHistory/HRSD_History_Chapter1.pdf.

McCarty, J. A., and L. J. Shrum, 2001: The influence of individualism, collectivism, and locus of control on environmental beliefs and behavior. J. Public Policy Mark., 20, 93-104, https://doi.org/10.1509/jppm.20.1.93.17291.

McKiven, H. M., Jr., 2007: The political construction of a natural disaster: The yellow fever epidemic of 1853. J. Amer. Hist., 94, 734-742, https://doi.org/10.2307/25095134.
Melosi, M. V., 2008: The Sanitary City: Environmental Services in Urban America from Colonial Times to the Present. University of Pittsburgh Press, 354 pp.

Morren, M., and A. Grinstein, 2016: Explaining environmental behavior across borders: A meta-analysis. J. Environ. Psychol., 47, 91-106, https://doi.org/10.1016/j.jenvp.2016.05.003.

Ogle, M., 1999: Water supply, waste disposal, and the culture of privatism in the mid-nineteenth century American city. J. Urban Hist., 25, 321-347, https://doi.org/10.1177/ 009614429902500302.

Patterson, D. K., 1992: Yellow fever epidemics and mortality in the United States, 1693-1905. Soc. Sci. Med., 34, 855-865, https:// doi.org/10.1016/0277-9536(92)90255-O.

Plyer, A., C. Heffernan, B. Espinosa, and K. Smith, 2017: The coastal index: Tracking development of the water management cluster in Southeast Louisiana. The Data Center, 76 pp., https://s3.amazonaws.com/gnocdc/reports/ TheDataCenter_TheCoastalIndex2017.pdf.

Postell, W. D., 1942: Edward Hall Barton, sanitarian. Annals of Medical History, 3rd Series, Vol. 4, P.B. Hoeber, 370-381.

Richmond, P. A., 1954: American attitudes toward the germ theory of disease (1860-1880). J. Hist. Med. Allied Sci., IX, 428-454, https://doi.org/10.1093/jhmas/IX.4.428.

Strauss, B. H., S. Kulp, and A. Levermann, 2015: Carbon choices determine US cities committed to futures below sea level. Proc. Natl. Acad. Sci., 112, 13 508-13 513, https://doi.org/ 10.1073/pnas.1511186112.

Tarr, J. A., J. McCurley, F. C. McMichael, and T. Yosie, 1984: Water and wastes: A retrospective assessment wastewater technology in the United States, 1800-1932. Technol. Cult., 25, 226-263, https://doi.org/10.2307/3104713.

Troesken, W., 2001: Race, disease, and the provision of water in American cities, 1889-1921. J. Econ. Hist., 61, 750-776, https:// doi.org/10.1017/S0022050701030066.

U.S. Army Corps of Engineers, 2018: Final integrated city of Norfolk coastal storm risk management feasibility study/ environmental impact statement. U.S. Environmental Protection Agency, Region 3, 506 pp., https:/usace.contentdm.oclc.org/utils/ getfile/collection/p16021 coll7/id/8557.

Waring, G. E., Jr., 1891: Sewerage and Land-Draining. 3rd ed. G. Van Nostrand Company, 406 pp. 